\title{
Risk recognition and variability in escape responses among intertidal molluskan grazers to the sun star Heliaster helianthus
}

\author{
Joan B. Escobar, Sergio A. Navarrete* \\ Estación Costera de Investigaciones Marinas (ECIM), and Center for Advanced Studies in Ecology \& Biodiversity (CASEB), \\ Pontificia Universidad Católica de Chile, CP 6513677, Santiago, Chile
}

\begin{abstract}
Escape responses are a common form of inducible defense in the presence of a predator, which can be species-specific and adaptive. While conditions for their evolution have been amply investigated, little is known about variability in prey responses over the range of variation in predation risks typical of most systems. We characterized escape responses of 4 intertidal grazers (2 chitons, 2 fissurellid limpets) to the sunstar Heliaster helianthus. Comparisons were made among sites of apparently distinct predation risks: high risk, where the grazers constitute a significant portion of $H$. helianthus diet; moderate risk, where $H$. helianthus primarily consume preferred mussel prey; no risk of predation, where prey exist beyond the southern geographic limit of $H$. helianthus. Prey responses were highly specific to the $H$. helianthus stimulus. Escape responses differed among grazer species, but these differences did not correspond to taxonomic relatedness, nor to their intertidal vertical distribution. No differences in escape responses were observed between sites where $H$. helianthus exhibit different diets, suggesting that these grazer species cannot 'perceive' and/or respond to this apparent change in predation risk. In contrast, a greater proportion of individuals of all 4 species responded to the $H$. helianthus cue, predator recognition was significantly faster, and distance traveled after stimulation was greater at sites of predator-prey coexistence than at the site beyond the predator's geographic range. Thus, longer contact history with the predator appears to favor greater capacity to display escape responses in all species examined. We highlight the importance of evaluating phenotypic responses to predators under natural conditions and across natural gradients of predation risks.
\end{abstract}

KEY WORDS: Inducible defense - Escape response $\cdot$ Predator-prey coexistence $\cdot$ Rocky intertidal · Heliaster helianthus

Resale or republication not permitted without written consent of the publisher

\section{INTRODUCTION}

Many experimental studies have demonstrated that, through their consumption of prey, predators can have significant effects on the local structure, dynamics and diversity of rocky intertidal communities (Paine 1966, Paine et al. 1985, Menge et al. 1986, Navarrete \& Menge 1996, Navarrete \& Castilla 2003). Predators not only have direct effects on prey populations and their communities by causing mortality of prey individuals, but they can also induce non-consumptive effects in the form of reversible or non-reversible phenotypical changes in prey traits, such as morphology (e.g. Lively 1986, Appleton \& Palmer 1988, Caro \& Castilla 2004, Caro et al. 2008), growth (Peckarsky et al. 1993, Yamada et al. 1998), and behavior (Harrold 1982, Côté \& Jelnikar 1999, Espoz \& Castilla 2000, Trussell et al. 2006, and see Havel 1987, Stearns 1989, Harvell 1990, Lima 1998 and Miner et al. 2005 for reviews). Indeed, several authors have argued that non-consumptive effects of predation might be equally or even more important than consumptive effects on prey distribution, prey growth rates and even on population abundance and community dynamics (Werner et al. 
1983, Kneib 1987, Holbrook \& Schmitt 1988, Richardson \& Brown 1992, Sih 1997, Yamada et al. 1998, Resetarits 2001, Trussell et al. 2006, Peckarsky et al. 2008).

Plastic responses of prey can be adaptive when they are effective in reducing the risk or probability of being eaten, and the response or reaction norm is inheritable (Stearns 1989, Miner et al. 2005). Typically, predation risks can be reduced through: (1) reducing the probability of encounter with the predator, which is called 'avoidance', or (2) reducing the probability of prey death during an encounter, which in mobile prey usually takes the form of an 'escape response' (Vermeij 1982, Sih 1984, Miner et al. 2005). Effective escape responses require the ability to detect and respond to predators before an actual attack, usually through the perception of visual, chemical, and/or tactile cues (Sih 1997, Trussell et al. 2006). In marine systems, escape responses are a widespread and often effective strategy to reduce attacks by comparatively slow-moving benthic predators (Schmitt 1981, Harrold 1982, Vermeij 1982, Espoz \& Castilla 2000, Miner et al. 2005).

The conditions for the evolution of inducible defenses have been amply investigated, but our understanding of variability of these responses, particularly over geographic scales, is still poor (Sanford et al. 2003, Kishida et al. 2007, Long \& Trussell 2007). In the case of predators and their prey, although they typically coexist along large portions of their geographic ranges, often there are areas (e.g. islands) or portions of the geographic range where prey are free of the predator species that elicit a particular and specific phenotypic response (Trussell 2000, Sanford et al. 2003, Kishida et al. 2007). At sites where predators are naturally absent for extended periods of time, local populations of prey are relieved from the pressure exerted by predation and thus they do not experience the corresponding predatory cues. The fixation and specificity of the antipredator behaviors may be diminished at these sites, especially when the development of the anti-predator responses is associated with high direct or indirect energetic costs (Lima \& Dill 1990, Lima 1998, Blumstein \& Daniel 2005). For instance, larval populations of the salamander Ambystoma barbouri showed a significant inverse relationship between the frequency of heritable anti-predator behavior and the level of isolation from their main predators (Storfer \& Sih 1998). Similarly, Kishida et al. (2007) showed that isolation of Rana pirica tadpoles on islands without predators leads to a lower capacity to express genetically controlled inducible defenses. In addition, local variability in predator traits such as feeding behavior or diet has also been shown to induce variability in prey escape responses in freshwater organisms (Laurila et al. 1997, Sullivan et al. 2004). Thus, in some systems it appears that prey can assess predation risk, based not only on the presence of or encounter rates with the predator, but also on the existence of other prey species, which can alter the risks of being eaten.

In coastal marine systems, where many species of predators and their prey have planktonic life stages and the dispersal of larvae is regulated not only by biological factors, but also by oceanographic features (Roughgarden et al. 1988, Eckman 1996, Wieters et al. 2008), uncertainty about predation risk at a new site can be very high. Therefore, inducible prey responses and the ability to recognize predator species as a mortality risk can represent important evolutionary advantages in these systems. Here we evaluate the regional variability in prey responses of 4 intertidal mollusks to their main predator, the sunstar Heliaster helianthus. Experiments were conducted under different scenarios of predator-prey coexistence, at 3 sites with distinct predation risks: high risk, where the molluskan grazers constitute a significant portion of $H$. helianthus diet; moderate risk, where predator and prey coexist, but $H$. helianthus primarily consume preferred, alternate prey; and no risk from this predator, where prey exist beyond the southern geographic range limit of H. helianthus.

\section{The predator-prey system}

The sunstar Heliaster helianthus is the most conspicuous intertidal predator in the SE Pacific, from $2^{\circ} \mathrm{N}$ in Ecuador to around $35^{\circ} \mathrm{S}$ in central Chile. At many sites in central Chile, this species plays a key role in the structure of intertidal communities by controlling the abundance of the competitively dominant mussel Perumytilus purpuratus (Paine et al. 1985, Navarrete \& Castilla 2003). Although mussels are preferred prey, the diet of $H$. helianthus also includes a wide variety of sessile and mobile species, including barnacles, tunicates, limpets, sea urchins, snails and chitons (Castilla 1981, Paine et al. 1985, Tokeshi et al. 1989, Navarret \& Manzur 2008). At sites where mussels and barnacles are scarce, limpets and chitons become the main food source for $H$. helianthus (Navarrete \& Manzur 2008, Barahona \& Navarrete 2010). In the present study, we focus on 4 species of molluskan grazers; the keyhole limpets Fissurella limbata and F. crassa, which occupy the low- and mid-intertidal zones, respectively, from $10^{\circ} \mathrm{S}$ to $42^{\circ} \mathrm{S}$ (Oliva \& Castilla 1992), and the chitons Acanthopleura echinata and Chiton granosus, which are abundant in the low- and mid-intertidal zones, respectively, from $15^{\circ} \mathrm{S}$ to $55^{\circ} \mathrm{S}$ (Otaíza \& Santelices 1985, Rivadeneira et al. 2002, Aguilera \& Navarrete 2007). Since the density of the predator is consistently higher in the low- than in the mid-intertidal zone (Navarrete \& Manzur 2008), higher predator-prey 
encounter rates are expected on the low shore. Therefore, low-shore prey species could exhibit stronger, more widespread escape responses, regardless of taxonomic identity.

Although the biogeographical range of Heliaster helianthus overlaps substantially with these common grazers, the range of these prey extends more than $700 \mathrm{~km}$ south of the range limit of $H$. helianthus (Fig. 1). In this southern region, no other intertidal seastars play the strong predatory role of $H$. helianthus (Castilla 1981, Castilla \& Paine 1987). The selection of these species allowed us to compare responses among closely and distantly related mollusk species (fissurellids, chitons), among species occupying the low- and the mid-intertidal zones, among sites with distinct predation risk scenarios, and between sites of coexistence with and sites of isolation from the predator.

\section{MATERIALS AND METHODS}

Specificity of grazer escape responses. All trials simulating predator-prey encounters were conducted in the field. In order to characterize behavioral escape responses and evaluate the specificity in the response to Heliaster helianthus, we simulated encounters between the predator and the 4 grazer species (Acanthopleura echinata, Chiton granosus, Fissurella crassa and F. limbata) on the rocky shore of the Estación Costera de Investigaciones Marinas (ECIM) at Las Cruces in central Chile $\left(33^{\circ} 30^{\prime} \mathrm{S}, 71^{\circ} 30^{\prime} \mathrm{W}\right)$. For each assay, we removed a $H$. helianthus individual (mean diameter $192.3 \mathrm{~mm}, \mathrm{SD} 4.7 \mathrm{~mm}$ ) from the substrate and touched a randomly chosen prey individual with one of the sunstar arms. Each sunstar was used in a maximum of 3 assays and then returned to the original position. Following the same protocol and to evaluate the specificity of the response, we conducted trials with the smaller seastar Stichaster striatus, which coexist with $H$. helianthus, but do not prey on juveniles or adults of the selected grazer species. In order to reduce potential confusion in the results, we did not use seastar individuals with evident signs of damage in their arms, tube feet or with signs of being in the spawning stage. We also included a control for mechanical stimulus, consisting of a plastic tube with which we touched the prey. A total of 20 trials for each treatment were conducted using different prey individuals. After trials, we registered the size of prey individuals (maximum shell length).

Based on preliminary observations, we identified 3 distinct sequential stages in the escape response: (1) the first stage, 'recognition', in which individuals lift the shell off the substratum, or slightly undulate the belt in the case of chitons. Individuals of Fissurella

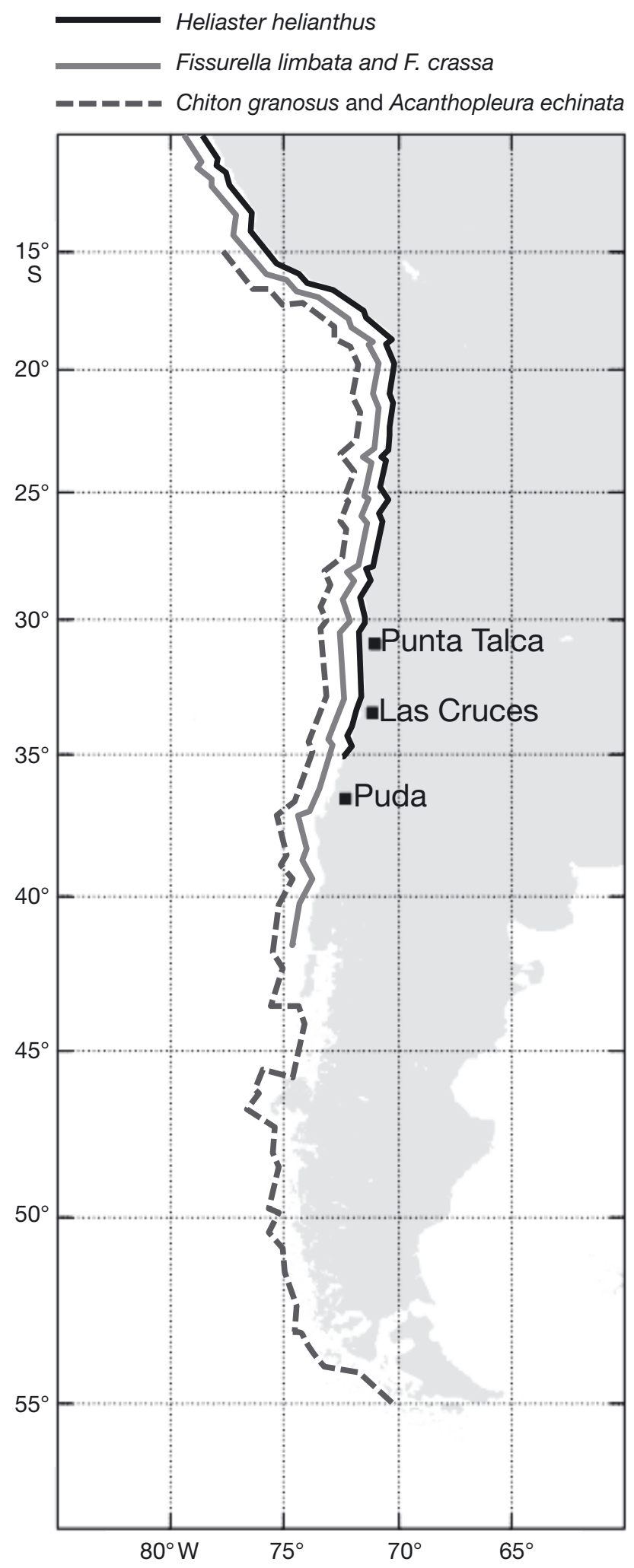

Fig. 1. North to south geographic ranges of the predator (Heliaster helianthus) and the grazer species (Fissurella crassa, F. limbata, Chiton granosus and Acanthopleura echinata) along the southeastern Pacific coast. The location of the 3 study sites is also indicated 
spp., would also extend the cephalic tentacles. (2) The second stage, 'searching', was characterized by a fast, rotating movement to both sides of the shell, apparently searching for a pathway to move. (3) The final stage, 'running', was defined as active displacement of individuals away from the point of contact. Using a digital chronometer we registered the starting and the ending time of each stage of the response. We used the time elapsed between physical contact and the first stage (recognition) as a proxy for the ability to recognize the predator. Also, in the cases where the third stage (running) was displayed, we recorded the total distance traveled until individuals completely stopped moving and used this distance as a proxy for the magnitude of response. Since the 4 study species have different body lengths (average length: $135.3 \mathrm{~mm}$ for Acanthopleura echinata, $55.0 \mathrm{~mm}$ for Chiton granosus, $72.5 \mathrm{~mm}$ for F. limbata and $69.3 \mathrm{~mm}$ for F. crassa), we attempted to reduce the variability attributed to different individual sizes by expressing the distance traveled in units of body length (distance traveled per individual body length). The velocity, accordingly, was expressed as the mean distance (in number of body lengths) divided by the duration of the running stage. We used standardized distances so that differences among species, if any, were not a simple consequence of inter-specific differences in body size but reflected species-level traits (see also Espoz \& Castilla 2000). We also compared absolute distances in centimeters.

Among-site variability in escape responses. In order to examine variability at sites of coexistence between Heliaster helianthus and its prey, we repeated the same experiments described above for Las Cruces at a site located $400 \mathrm{~km}$ to the north, Punta Talca (Fig. 1). Punta Talca has lower mussel percentage cover and recruitment rates than Las Cruces (Broitman et al. 2001, Navarrete et al. 2005). Densities of $H$. helianthus are similar at both sites (13 individuals [ind.] $\mathrm{m}^{-2}$ at Punta Talca, 15 ind. $\mathrm{m}^{-2}$ at Las Cruces; Navarrete \& Manzur 2008), but its diet is different, showing higher propotions of limpets and chitons at Punta Talca (Navarrete \& Manzur 2008, Barahona \& Navarrete 2010). Since the $H$. helianthus diet at Las Cruces consists mostly of mussels, we considered it to be particularly interesting to evaluate variation in prey responses between these 2 sites, using frequency in the diet of the predator as a proxy for predation risk. Twenty individuals of each prey species were tested following the protocol described above.

To examine variability and potential fixation of the grazers escape response in areas without Heliaster helianthus, we conducted the same assays at Puda, a site located $400 \mathrm{~km}$ south of Las Cruces and over $250 \mathrm{~km}$ beyond the southern geographic endpoint of $H$. helianthus (Fig. 1). At this site, trials were con- ducted with $H$. helianthus individuals collected at Las Cruces and transported live in coolers at low temperature. Trials were finished within $2 \mathrm{~d}$ of collection and sunstars were returned to the original collecting area at Las Cruces. Before release back to the field, sunstars were used in short field trials with the same study prey species to ensure the sunstars retained the capacity to elicit escape responses. Since the seastar Stichaster striatus did not elicit grazer escape responses (see 'Results'), we did not use them at Punta Talca or Puda. Between 19 and 25 individual prey (replicates) were used depending on species.

Statistical analysis. Since in several cases neither Stichaster striatus nor the mechanical control elicited escape responses of individuals (see 'Results', Fig. 2), no statistical analysis could be conducted or was necessary to compare the 3 treatments. Considering only assays conducted with Heliaster helianthus, 2 separate sequential analyses were conducted using log-linear modeling, a generalized linear model extension of the traditional contingency tables (Agresti 1996). These analyses determined: (1) whether the frequency of individuals executing the 3 stages of the escape response varied among the 4 grazer species between the sites of Las Cruces and Punta Talca (coexistence sites), and (2) whether the frequency of individuals executing the third and most clear stage of the escape response ('running') in the 4 grazer species varied between the 2 sites of predator-prey coexistence (Punta Talca and Las Cruces) and the site with no predators (Puda). For the latter analysis, and after the detection of no statistical differences between the sites of coexistence (see 'Results'), we pooled the data for Las Cruces and Punta Talca. Note that in this manner, data on frequency of individuals were used more than once. However, because the analyses tested distinct a priori hypotheses, we did not adjust probabilities. In any case, a simple Bonferroni adjustment would not alter our conclusions (see 'Results').

The time taken by individuals to recognize the stimulus and execute the escape response was analyzed with a 2-way factorial ANOVA with 'Species' and 'Site' as fixed factors. All 3 sites were considered in this analysis. Planned orthogonal contrasts were then used to evaluate specific hypotheses of interest (Milliken \& Johnson 1984). The main effect orthogonal contrasts for the factor 'site' tested for: (1) differences in recognition time between the 2 sites of predator-prey coexistence and (2) differences between the 2 coexistence sites and the site of no predator-prey coexistence (Puda). The main effect orthogonal contrasts for the factor 'species' tested for: (1) differences in recognition time between mid-intertidal species (Fissurella crassa and Chiton granosus) and low-intertidal species (F. limbata and Acanthopleura echinata), (2) differ- 
ences between the 2 keyhole limpet species, and (3) differences between the 2 chiton species. Since the ANOVA showed a significant interaction term, we used orthogonal interaction contrasts to evaluate whether this interaction term was due to variation in recognition time between sites of predator-prey coexistence or between these 2 sites and the site of no coexistence (see examples in Milliken \& Johnson 1984).

The same ANOVA and planned contrasts approach were conducted to evaluate differences in standardized distances traveled by individuals and velocities of displacement.

\section{RESULTS}

\section{Specificity of grazer escape responses}

In Las Cruces, individuals of the 4 grazer species showed low levels of the recognition response stage to the Stichaster striatus stimulus (Fig. 2). Only 15\% of Fissurella limbata, $10 \%$ of Acanthopleura echinata and F. crassa, and none of Chiton granosus displayed the third stage of the escape response (running) to this

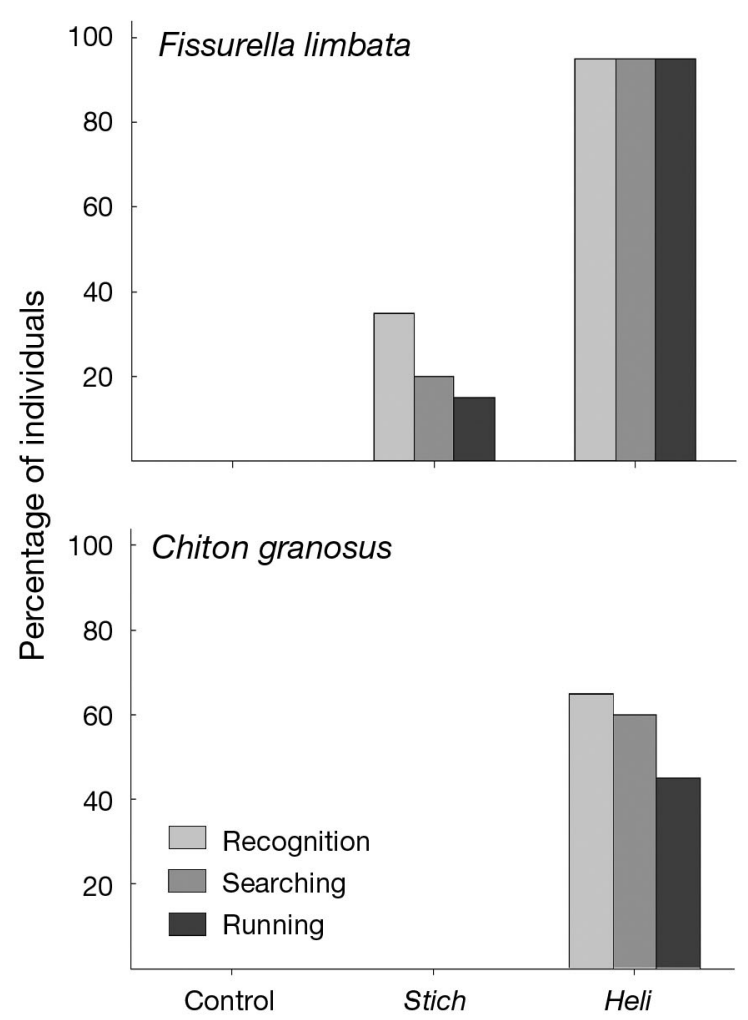

seastar species. The mechanical stimulus treatment did not elicit any response at all in the grazers, except in $5 \%$ of $A$. echinata, but these few individuals did not proceed into the second, searching stage of the escape response (Fig. 2). These results contrast sharply with the high percentage of individuals of all species responding to the Heliaster helianthus treatment. The lowest frequency of response to $H$. helianthus was observed in C. granosus, with $65 \%$ of individuals exhibiting the first, recognition stage of the response, while more than $90 \%$ of individuals of the other grazer species recognized the $H$. helianthus stimulus (Fig. 2). Similar patterns were observed for the second and third stages of the escape response (Fig. 2), with $C$. granosus again slightly less responsive than the other species (Table 1).

\section{Among-site variability in escape responses}

There were no differences in the percentage of individuals exhibiting the running stage of the escape response between Las Cruces and Punta Talca, the 2 sites of predator-prey coexistence (Fig. 3, Table 1). As
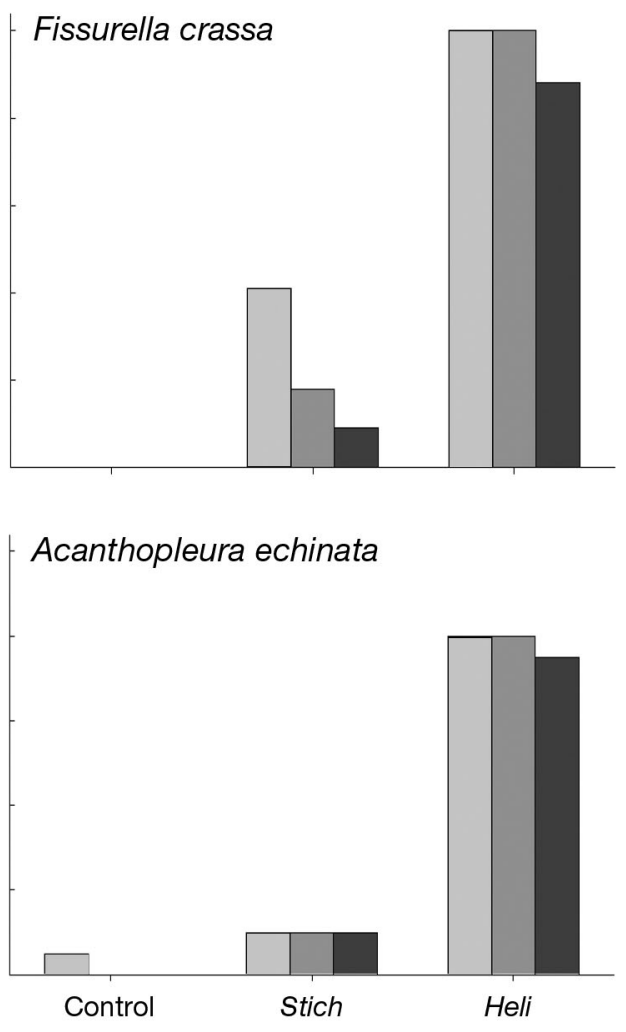

Treatment

Fig. 2. Fissurella limbata, F. crassa, Chiton granosus and Acanthopleura echinata. Frequency (\%) of individuals displaying the different stages of escape response for the 4 intertidal grazer species. Treatments: Control $=$ purely mechanical stimulus; Stich $=$ contact with the small seastar Stichaster striatus; Heli = contact with the sunstar Heliaster helianthus 
at Las Cruces, Chiton granosus showed the lowest frequency of individuals $(30 \%)$ exhibiting the running stage of the response to Heliaster helianthus, while most individuals of the other species $(74 \%$ Fissurella crassa and $100 \%$ of F. limbata and Acanthopleura echinata individuals) recognized the stimulus and executed an active escape. Thus, differences in frequencies among grazing species were consistent between these 2 sites (Table 1, Fig. 3), regardless of observed differences in predator diet.

The time taken to recognize the Heliaster helianthus stimulus varied significantly among species, with Chiton granosus exhibiting significantly longer recognition times than all other grazer species, and no differences between the 2 closely related fissurellid species (Fig. 4, Table 2, contrasts a, b). Significant differences were found between low- and mid-intertidal species (Table 2, contrast c), but these differences were driven by the slower recognition time of the mid-intertidal species, C. granosus (Fig. 4). Similar to the frequency of individuals responding to stimulus, the mean time to recognize the stimulus at Punta Talca was not different to that observed at Las Cruces. Thus, among-species

Table 1. Fissurella limbata, F. crassa, Chiton granosus and Acanthopleura echinata. Log-linear analysis of the 2-way contingency table for the 2 sites of coexistence ('Site', Las Cruces versus Punta Talca) and the number of individuals of the 4 grazer species ('Species') displaying the third stage of the escape response (running). Bold: significance at $\alpha=0.05$

\begin{tabular}{|lrcr|}
\hline Source & $\mathrm{G}^{2}$ & $\mathrm{df}$ & \multicolumn{1}{c|}{$\mathrm{p}$} \\
\hline Species & 35.66 & 3 & $\mathbf{< 0 . 0 0 0 1}$ \\
Site & 1.64 & 1 & 0.2003 \\
Species $\times$ Site & 3.08 & 3 & 0.3795 \\
\hline
\end{tabular}

differences in predator recognition times were conserved between the 2 sites of predator-prey coexistence, regardless of variation in predation risk (Table 2, contrast d).

In contrast, the magnitude of response as measured by distance traveled was not wholly consistent between sites of high and moderate predation risk. Acanthopleura echinata showed the longest escape distances, followed by Fissurella limbata, Chiton granosus and, lastly, F. crassa. These differences are associated with specific differences in body size (see 'Materials and methods'), so we analyzed the distances traveled by individuals standardized by their body sizes. These results showed that the distances traveled at the end of the running response were significantly shorter for F. crassa than for all other species (Fig. 5, Table 3, con-

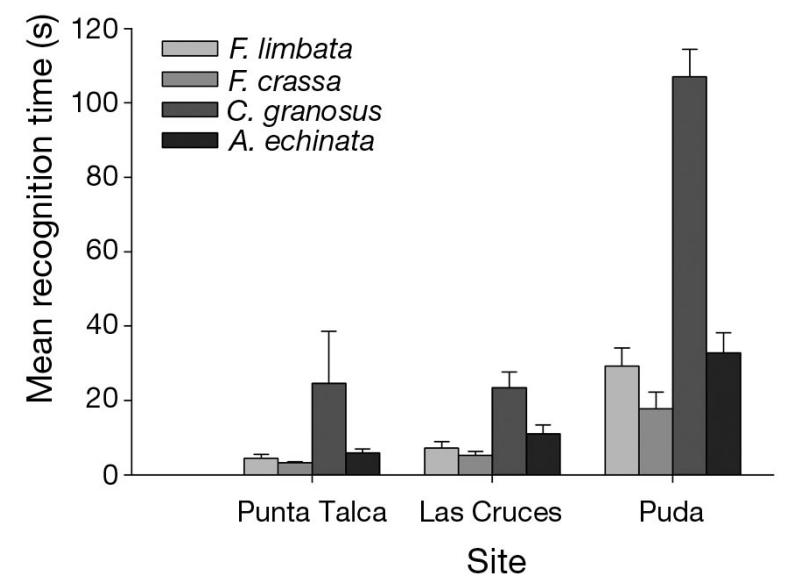

Fig. 4. Fissurella limbata, F. crassa, Chiton granosus and Acanthopleura echinata. Time (mean $+\mathrm{SE}$ ) taken by individuals of the 4 grazer species to recognize the stimulus by the sunstar Heliaster helianthus at the 3 study sites

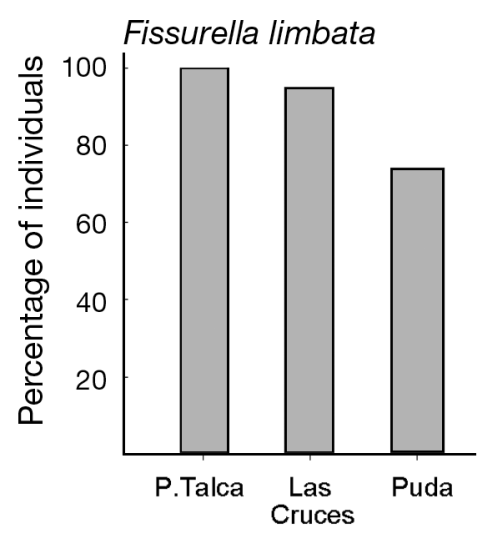

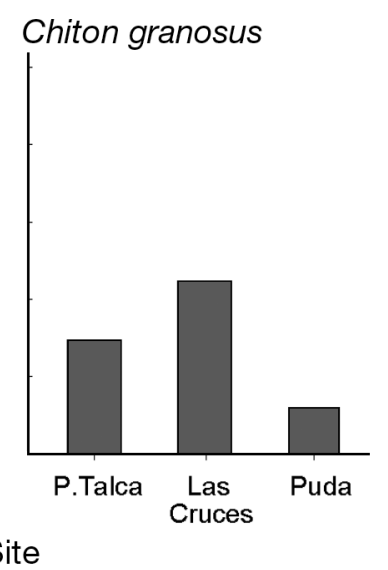

Fig. 3. Fissurella limbata, F. crassa, Chiton granosus and Acanthopleura echinata. Percentage of individuals executing the 'running' stage of the escape response after the contact with the sunstar Heliaster helianthus at the 3 study sites for the 4 grazer species 
Table 2. Fissurella limbata, F. crassa, Chiton granosus and Acanthopleura echinata. Two-way ANOVA for the recognition times of the 4 grazer species at the 3 study sites. Orthogonal planned contrasts are presented under each of the ANOVA main factors for Species $(\mathrm{a}-\mathrm{c})$, Site $(\mathrm{d}-\mathrm{e})$ and interaction term (contrast combinations). Bold: significant values

\begin{tabular}{|lrrrr|}
\hline Source & df & SS & $F$ & p \\
\hline Species & 3 & 36621.5 & 48.52 & $<\mathbf{0 . 0 0 0 1}$ \\
Main effect contrasts for 'Species' & & & & \\
a. C. granosus vs. A. echinata & 1 & 21455.2 & 85.27 & $<\mathbf{0 . 0 0 0 1}$ \\
b. F. crassa vs. F. limbata & 1 & 676.2 & 2.69 & 0.1027 \\
c. Mid zone vs. Low zone & 1 & 10762.6 & 42.78 & $<\mathbf{0 . 0 0 0 1}$ \\
Site & 2 & 31289.5 & 62.18 & $<\mathbf{0 . 0 0 0 1}$ \\
Main effect contrasts for 'Site' & & & & \\
d. Las Cruces vs. Punta Talca & 1 & 669.5 & 2.66 & 0.10446 \\
e. Las Cruces and Punta Talca vs. Puda & 1 & 30804.86 & 122.44 & $<\mathbf{0 . 0 0 0 1}$ \\
Species $\times$ Site & & & & \\
Interaction contrasts & 6 & 7255.8 & 4.81 & $\mathbf{0 . 0 0 0 1}$ \\
a $\times$ d & & & & \\
b $\times$ d & 1 & 21.7 & 0.09 & 0.7695 \\
C $\times$ d & 1 & 11.7 & 0.05 & 0.8297 \\
a $\times$ e & 1 & 2.7 & 0.01 & 0.9176 \\
b $\times$ e & 1 & 3318.8 & 13.19 & $\mathbf{0 . 0 0 0 4}$ \\
C $\times$ e & 1 & 527.9 & 2.10 & 0.1491 \\
Residual & 1 & 1169.5 & 4.65 & $\mathbf{0 . 0 3 2 3}$ \\
\end{tabular}

Species $\times$ Site interaction involving the 2 sites of coexistence (Table 3). Although generally similar among-species differences were observed in the velocity reached by individuals during the running stage, these differences were not statistically significant, nor did they vary among any of the study sites (2-way ANOVA, p > 0.05 for all comparisons).

A very different pattern of escape response was observed when we compared the behavior of grazers at the 2 sites of predator-prey coexistence to that at Puda, the site beyond the geographic range of Heliaster helianthus. (1) All grazer species at Puda exhibited a decrease in the percentage of individuals recognizing the predator and displaying the running stage of the response (Fig. 3, Table 4). (2) Among the individuals that did recognize the predator cue, the mean recognition time increased greatly in all 4 species (Fig. 4, Table 2, contrast e). (3) The magnitude of response was lower

trast b). Shorter distances traveled were also observed among mid-intertidal species than those at lower intertidal elevations (Table 3, contrast c), but these differences were driven primarily by F. crassa (Fig. 5). Traveled distances were generally significantly longer at Punta Talca than Las Cruces (Table 3, contrast d), and although among-species differences varied slightly between these 2 sites (Fig. 5), there was no significant

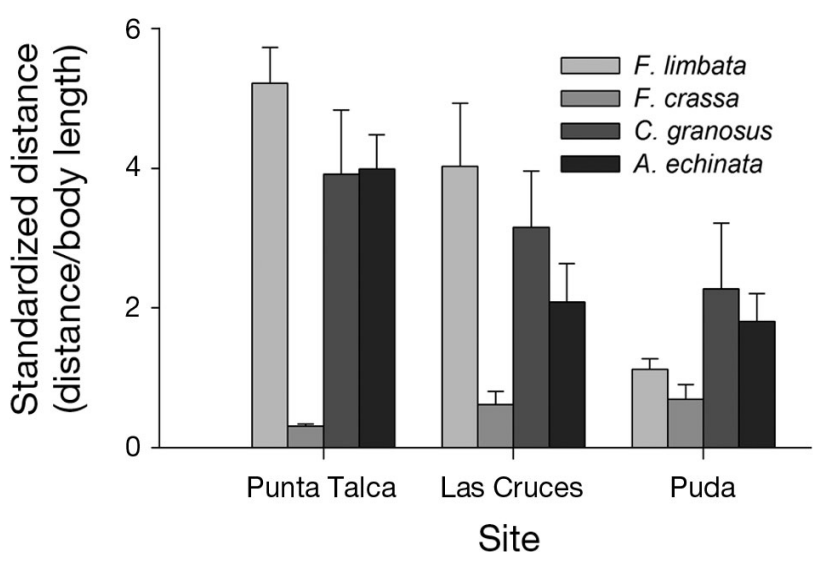

Fig. 5. Fissurella limbata, F. crassa, Chiton granosus and Acanthopleura echinata. Standardized distances (mean distance in $\mathrm{cm}$ per body length + SE) covered by the 4 grazer species after contact with sunstar Heliaster helianthus at the 3 study sites at Puda than at Las Cruces and Punta Talca. Prey species traveled significantly shorter distances (Fig. 5, Table 3, contrast e), but the magnitude of the effect varied among species (Table 3, interaction contrasts).

\section{DISCUSSION}

In this study, we evaluated the specificity of escape responses of benthic grazers in the field and tested whether responses to predator cues were variable under distinct natural scenarios of predation risk defined by changes in predator diet and predator-prey coexistence. Our results showed that although all 4 grazer species had highly specific responses to their main predator, the sunstar Heliaster helianthus, prey responses between sites with different predator diet were not different, while strong differences were observed between sites of coexistence and the site where the predator is naturally absent. Thus, differences in the local diet of $H$. helianthus between sites did not produce important changes in escape responses of the focal species in this study, suggesting they cannot perceive or respond effectively to this change in predation risk, or that relatively rare predation events maximize the escape behaviors. Together, our results suggest that the observed escape responses are controlled by a combination of fixed and learned behaviors. 
Table 3. Fissurella limbata, F. crassa, Chiton granosus and Acanthopleura echinata.Two-way ANOVA for the distances traveled (standardized by body length) of the 4 grazer species at the 3 study sites. Orthogonal planned contrasts are presented under each of the ANOVA main factors for Species $(\mathrm{a}-\mathrm{c})$, Site $(\mathrm{d}-\mathrm{e})$ and interaction term (contrast combinations). Bold: significant values

\begin{tabular}{|lrrrr|}
\hline Source & df & \multicolumn{1}{c}{ SS } & $F$ & p \\
\hline Species & 3 & 255.9 & 21.46 & $<\mathbf{0 . 0 0 0 1}$ \\
Main effect contrasts for 'Species' & & & & \\
a. C. granosus vs. A. echinata & 1 & 2.7 & 0.68 & 0.4095 \\
b. F. crassa vs. F. limbata & 1 & 232.6 & 58.49 & $<\mathbf{0 . 0 0 0 1}$ \\
C. Mid zone vs. Low zone & 1 & 47.4 & 11.92 & $<\mathbf{0 . 0 0 0 7}$ \\
Site & 2 & 67.7 & 33.85 & $\mathbf{0 . 0 0 0 3}$ \\
Main effect contrasts for 'Site' & & & & \\
d. Las Cruces vs. Punta Talca & 1 & 21.7 & 5.45 & $\mathbf{0 . 0 2 0 7}$ \\
e. Las Cruces and PuntaTalca vs. Puda & 1 & 48.6 & 12.22 & $\mathbf{0 . 0 0 0 6}$ \\
Species $\times$ Site & 6 & 99.2 & 4.16 & $\mathbf{0 . 0 0 0 6}$ \\
Interaction contrasts & & & & \\
a $\times$ d & 1 & 3.3 & 0.84 & 0.3596 \\
b $\times$ d & 1 & 11.9 & 3.02 & 0.0842 \\
c $\times$ d & 1 & 12.1 & 3.03 & 0.0834 \\
a $\times$ e & 1 & 0.01 & 0.01 & 0.9791 \\
b $\times$ e & 1 & 73.5 & 18.49 & $<\mathbf{0 . 0 0 0 1}$ \\
c $\times$ e & 1 & 19.9 & 5.01 & $\mathbf{0 . 0 2 6 5}$ \\
Residual & 194 & 691.8 & & \\
\hline
\end{tabular}

Table 4. Fissurella limbata, F. crassa, Chiton granosus and Acanthopleura echinata. Log-linear analysis of the 2-way contingency table for the 2 sites of predator-prey coexistence pooled together versus the site where the predator is absent ('Coexistence', Punta Talca and Las Cruces versus Puda), and the number of individuals of the 4 grazer species ('Species') displaying the third stage of the escape response (running). Bold: significance at $\alpha=0.05$

\begin{tabular}{|lrcr|}
\hline Source & $\mathrm{G}^{2}$ & $\mathrm{df}$ & \multicolumn{1}{c|}{$\mathrm{p}$} \\
\hline Species & 70.20 & 3 & $\mathbf{< 0 . 0 0 0 1}$ \\
Coexistence & 17.52 & 1 & $\mathbf{< 0 . 0 0 0 1}$ \\
Species $\times$ Coexistence & 5.18 & 3 & 0.1591 \\
\hline
\end{tabular}

Although we did not include a direct evaluation of the adaptive nature of the escape responses, the effectiveness of these responses in reducing predation rates is supported by our field observations and those of other authors (Dayton et al. 1977, Castilla 1981, Gaymer \& Himmelman 2008) along the coast of Chile. Often we have seen keyhole limpets or the large chiton Acanthopleura echinata abandoning their resting refuges and actively escaping from $H$. helianthus, which sometimes pursues the prey for over $30 \mathrm{~min}$. Frequently, these chases are unsuccessful and the predator returns to lower intertidal levels.

The increased frequency of responding individuals, lower recognition time and, to some extent, the increased magnitude of response (distance traveled, see below) of all grazer species at sites where prey coexist with the predator suggest that longer contact history with the predator favors greater capacity to display escape responses. Previous studies in fresh water systems have also shown that predator response traits can be plastic and that prey living in the absence of signals by the predator indicating predation risk exhibit a reduced capacity to recognize and respond to attacks (Lima \& Dill 1990, Storfer \& Sih 1998, Kishida et al. 2007). Biogeographic and ecological records show that Heliaster helianthus is distributed from the equator to about $33^{\circ} \mathrm{S}$ (Guiler 1959, Brattstrom \& Johanssen 1983). Although there is no information about effective dispersal in the mollusk species, the distance $(>250 \mathrm{~km})$ to the experimental site at Puda, and the fact that these species have lecithotrophic larvae with only a moderate dispersal capacity of a few kilometers (Kinlan \& Gaines 2003), makes it unlikely that grazer individuals have dispersed from sites with the predator north of $33^{\circ} \mathrm{S}$. The increase in times necessary to react to a predator stimulus at sites where the predator is absent could therefore be the result of prey individuals lacking recent experience of the predator. On the other hand, the significant reduction in the fraction of individuals recognizing $H$. helianthus as a risk suggests a reduction in selection pressure favoring the display of the escape response in all grazer populations. Yet, an important fraction of the populations of all grazer species was still able to recognize and escape from the predator stimulus, despite the fact that they most likely never had direct experience of $H$. helianthus. Perhaps the ability to display inducible defense in these grazer species is an ancestral characteristic retained in the populations but modulated by the decreased predation risk. This would suggest that the responses are not that costly.

Except for changes in distance traveled by individuals, which are modulated by topological features of the general seascape (see below) and could also be a consequence of specific differences in body size, we did not find significant differences in escape responses between sites were Heliaster helianthus exhibit different diets and therefore exert different predation pressures on grazers. Analysis of diet and field observations show that $H$. helianthus consume more mobile prey (limpets, chitons) at Punta Talca than at Las Cruces, where the seastars consume mostly mussels 
and barnacles (Paine et al. 1985, Navarrete \& Manzur 2008, Barahona \& Navarrete 2010). This, together with increased movement of $H$. helianthus at Punta Talca (Barahona \& Navarrete 2010) suggests that grazer populations are indeed exposed to higher predation rates by the seastar at this site. While low levels of predation should be sufficient to maintain the escape response, we expected it to change in intensity or frequency at sites where the predator consumes mostly alternative prey. Yet, it appears that none of the grazer species can 'perceive' and/or respond to this apparent change in predation risk. Several laboratory studies have shown that prey can assess and respond to varying predation risks according to whether the predator feeds on alternative prey (e.g. Hagen et al. 2002, Shin et al. 2009, Bourdeau 2010). Our results suggest that under natural conditions of multiple cues and risks, this fine assessment may not be possible or effective in these 4 grazer species. If this fine risk assessment of the plastic response has a genetic basis, gene flow could swamp the local adaptation and homogenize expression of the plastic response across sites of varying predator diets, as experimentally shown by Storfer \& Sih (1998) among stream salamander populations. The spatial scale over which mussel beds are absent from the intertidal zone around Punta Talca (hundreds of kilometers, Navarrete et al. 2005) makes it difficult to believe that dispersal could be responsible for the lack of differences in escape responses. Yet, this possibility should be further evaluated with a series of experiments similar to those designed by Storfer \& Sih (1998).

Among the variables measured in the present study to assess grazers' escape responses, some are expected to be more conservative, i.e. frequency of individuals recognizing the predator and recognition time, and others more dependent on local environmental and topological conditions, i.e. distance traveled and velocity. Therefore, the observed inter-specific differences in the frequency of individuals that recognize the predator stimulus and their recognition times could be due to: (1) differences in evolutionary histories and structural constraints among species, (2) differences in the ratio of predation risk (due to predator feeding preferences among prey species) to the cost of the response, and/or (3) differences in the effectiveness of the response. In contrast, although inter-specific differences in distances traveled by individuals after a single predator stimulus must have a genetic and learning (experience) component, they are usually highly variable according to local seascape in order to be cost effective. Indeed, many studies have shown that movement rates and displacement distances in marine consumers are highly dependent on topography and other environmental conditions (e.g. Lipcius \& Hines 1986, Almeida et al. 2008). Further studies are therefore needed to determine the causes of inter-specific differences in escape responses. Our results do suggest, however, that phylogenetic baggage does not play an important role in maintaining these differences.

Our results show that some aspects of prey responses were correlated to the Heliaster helianthus foraging range across tidal elevations. Indeed, fewer individuals of the mid-intertidal species Chiton granosus responded to the predator and the individuals presented the longest recognition times among all the species studied. Secondly, the other mid-intertidal species, Fissurella crassa showed the shortest escape distance of all species. However, a larger number of mid- and lowintertidal species should be tested to separate effects of habitat (tidal level) from species-specific responses.

Understanding the complex relationship between predators and their mobile prey is key not only to the study of predator-prey dynamics and its evolution, but also to the comprehension of the role of nonconsumptive effects in the organization of intertidal communities. Our results show that the expression and magnitude of escape responses can vary across some geographic scenarios of predation risks (coexistence versus isolation), but not others (changes in predator diets). They also illustrate the importance of evaluating these responses under natural conditions and across natural gradients of predation risks occurring along the geographic range of predator-prey distributions. Careful thought must therefore be given to the selection of collecting sites for laboratory experiments and to the interpretation of these results for our understanding of predator-prey relationship under natural conditions.

Acknowledgements. We thank M. Parrague, M. Barahona, and G. Flores for invaluable assistance in the field. Comments and suggestions by J. Shinen on the manuscript are greatly appreciated. Grants from FONDECYT no. 1070335 and FONDAP Fondecyt 1501-0001 to S.A.N. provided financial support for this study. J.B.E. also acknowledges support from of the Andrew Mellon Foundation.

\section{LITERATURE CITED}

Agresti A (1996) An introduction to categorical data analysis. John Wiley \& Sons, New York, NY

Aguilera M, Navarrete SA (2007) Effects of Chiton granosus (Frembly, 1827) and other mollusk grazers on algal succession in mid-intertidal rocky shores of central Chile. J Exp Mar Biol Ecol 349:84-98

Almeida MJ, Flores AV, Queiroga H (2008) Effect of crab size and habitat type on the locomotory activity of juvenile shore crabs, Carcinus maenas. Estuar Coast Shelf Sci 80: 509-516

Appleton RD, Palmer AR (1988) Water-borne stimuli released by predatory crabs and damaged prey induce more predator-resistant shells in a marine gastropod. Proc Natl Acad Sci USA 85:4387-4391 
Barahona M, Navarrete SA (2010) Movement patterns of the seastar Heliaster helianthus in central Chile: relationship with environmental conditions and prey availability. Mar Biol 157:647-661

Blumstein DT, Daniel JC (2005) The loss of anti-predator behavior following isolation in islands. Proc Biol Sci 272: 1663-1668

Bourdeau PE (2010) Cue reliability, risk sensitivity and inducible morphological defense in a marine snail. Oecologia 162:987-994

Brattstrom H, Johanssen A (1983) Ecological and regional zoogeography of the marine benthic fauna of Chile. Sarsia 68:289-339

Broitman BR, Navarrete SA, Smith F, Gaines SD (2001) Geographic variation in southern Pacific intertidal communities. Mar Ecol Prog Ser 224:21-34

Caro AU, Castilla JC (2004) Predator-inducible defences and local intrapopulation variability of the intertidal mussel Semimytilus algosus in central Chile. Mar Ecol Prog Ser 276:115-123

- Caro AU, Escobar J, Bozinovic F, Navarrete SA, Castilla JC (2008) Phenotypic variability in byssus thread production of intertidal mussels induced by predators with different feeding strategies. Mar Ecol Prog Ser 372:127-134

Castilla JC (1981) Perspectivas de investigación en estructura y dinámica de comunidades intermareales rocosas de Chile Central II. Depredadores de alto nivel trófico. Med Am 5:190-215

Castilla JC, Paine RT (1987) Predation and community organization on Eastern Pacific, temperate zone, rocky intertidal shores. Rev Chil Hist Nat 60:131-151

> Côté IM, Jelnikar E (1999) Predator-induced clumping behaviour in mussels (Mytilus edulis Linnaeus). J Exp Mar Biol Ecol 235:201-211

> Dayton PK, Rosenthal RJ, Mahen LC, Antezana T (1977) Population structure and foraging biology of the predaceous Chilean asteroid Meyenaster gelatinosus and the escape biology of its prey. Mar Biol 39:361-370

- Eckman JE (1996) Closing the larval loop: linking larval ecology to the population dynamics of marine benthic invertebrates. J Exp Mar Biol Ecol 200:207-237

Espoz C, Castilla JC (2000) Escape responses of four Chilean intertidal limpets to sea stars. Mar Biol 137:887-892

- Gaymer CF, Himmelman JH (2008) A keystone predatory sea star in the intertidal zone is controlled by a higher-order predatory sea star in the subtidal zone. Mar Ecol Prog Ser 370:143-153

Guiler ER (1959) The intertidal ecology of the Montemar area, Chile. Pap Proc R Soc Tasman 93:33-58

Hagen NT, Andersen A, Stabell OB (2002) Alarm responses of the green sea urchin, Strongylocentrotus droebachiensis, induced by chemically labelled durophagous predators and simulated acts of predation. Mar Biol 140:365-374

Harrold C (1982) Escape responses and prey availability in a kelp forest predator-prey system. Am Nat 119:132-135

Harvell CD (1990) The ecology and evolution of inducible defenses. Quart Rev Biol 65:323-340

Havel JE (1987) Predator-induced defenses: a review. In: Kerfoot WC, Sih A (eds) Predation: direct and indirect impacts on aquatic communities. University Press of New England, Hanover, NH, p 263-278

> Holbrook SJ, Schmitt RJ (1988) The combined effects of predation risk and food reward on patch selection. Ecology 69:125-134

Kinlan BP, Gaines SD (2003) Propagule dispersal in marine and terrestrial environments: a community perspective. Ecology 84:2007-2020
Kishida O, Trussell GC, Nishimura K (2007) Geographic variation in a predator-induced defense and its genetic basis. Ecology 88:1948-1954

Kneib RT (1987) Predation risk and use of intertidal habitats by young fishes and shrimp. Ecology 68:379-386

Laurila A, Kujasalo J, Ranta E (1997) Different antipredator behaviour in two anuran tadpoles: effects of predator diet. Behav Ecol Sociobiol 40:329-336

Lima S (1998) Non-lethal effects in the ecology of predatorprey interactions. Bioscience 48:25-34

Lima SL, Dill LM (1990) Behavioral decisions made under the risk of predation: a review and prospectus. Can J Zool 68: $619-640$

- Lipcius RN, Hines AH (1986) Variable functional responses of a marine predator in dissimilar homogeneous microhabitats. Ecology 67:1361-1371

Lively CM (1986) Predator-induced shell dimorphism in the acorn barnacle Chthamalus anisopoma. Evolution 40: $232-242$

> Long JD, Trussell GC (2007) Geographic variation in seaweed induced responses to herbivory. Mar Ecol Prog Ser 333: $75-80$

> Menge BA, Lubchenco J, Gaines SD, Ashkenas LR (1986) A test of the Menge-Sutherland model of community organization in a tropical rocky intertidal food web. Oecologia 71:75-89

Milliken GA, Johnson DE (1984) Analysis of messy data, Vol 1: Designed experiments. Van Nostrand Reinhold, New York, NY

- Miner BG, Sultan SE, Morgan SG, Padilla DK, Relyea RA (2005) Ecological consequences of phenotypic plasticity. Trends Ecol Evol 20:685-692

Navarrete SA, Castilla JC (2003) Experimental determination of predation intensity in an intertidal predator guild: dominant versus subordinate prey. Oikos 100:251-262

> Navarrete SA, Manzur T (2008) Individual- and populationlevel responses of a keystone predator to geographic variation in prey. Ecology 89:2005-2018

Navarrete SA, Menge BA (1996) Keystone predation and interaction strength: interactive effects of predators on their main prey. Ecol Monogr 66:409-429

Navarrete SA, Wieters E, Broitman B, Castilla JC (2005) Scales of benthic-pelagic coupling and the intensity of species interactions: from recruitment limitation to top down control. Proc Natl Acad Sci USA 102: 18046-18051

Oliva D, Castilla JC (1992) Guía para el reconocimiento y morfometría de diez especies del género Fissurella Bruguiére 1789 (Mollusca: Gastropoda) comunes en las pesquerías y conchales indígenas de Chile Central y Sur. Gayana (Zool) 56:77-108

Otaíza R, Santelices B (1985) Vertical distribution of chitons (Mollusca: Polyplacophora) in the rocky intertidal zone of central Chile. J Exp Mar Biol Ecol 86:229-240

Paine RT (1966) Food web complexity and species diversity. Am Nat 100:65-75

Paine RT, Castilla JC, Cancino J (1985) Perturbation and recovery of starfish-dominated intertidal assemblages in Chile, New Zealand and Washington State. Am Nat 125: 679-691

Peckarsky BL, Cowan CA, Penton MA, Anderson C (1993) Sublethal consequences of stream-dwelling predatory stoneflies on mayfly growth and fecundity. Ecology 74: 1836-1846

> Peckarsky BL, Bolnick DA, Dill LM, Grabowski JH and others (2008) Revisiting the classics: considering nonconsumptive effects in textbook examples of predator-prey interactions. Ecology 89:2416-2425 
Resetarits WJ Jr (2001) Colonization under threat of predation: avoidance of fish by an aquatic beetle, Tropisternus lateralis (Coleaptera: Hydrophilidae). Oecologia 129: 155-160

Richardson TD, Brown KM (1992) Predation risk and feeding in an intertidal predatory snail. J Exp Mar Biol Ecol 163: 169-182

Rivadeneira M, Fernández M, Navarrete SA (2002) Latitudinal trends of species diversity in rocky intertidal herbivore assemblages: spatial scale and the relationship between local and regional species richness. Mar Ecol Prog Ser 245:123-131

Roughgarden J, Gaines S, Possingham H (1988) Recruitment dynamics in complex life cycles. Science 241:1460-1466

Sanford E, Roth MS, Johns GC, Wares JP, Somero GN (2003) Local selection and latitudinal variation in a marine predator-prey interaction. Science 300:1135-1137

Schmitt RJ (1981) Contrasting anti-predator defenses of sympatric marine gastropods (family Trochidae). J Exp Mar Biol Ecol 54:251-263

Shin PKS, Yang FY, Chiu MY, Cheung SG (2009) Cues from the predator crab Thalamita danae fed different prey can affect scope for growth in the prey mussel Perna viridis. Mar Freshw Behav Physiol 42:343-355

Sih A (1984) The behavioral response race between predator and prey. Am Nat 123:143-150

Sih A (1997) To hide or not to hide? Refuge use in a fluctuating environment. Trends Ecol Evol 12:375-376

Stearns SC (1989) The evolutionary significance of phenotypic plasticity. Bioscience 39:436-445

Editorial responsibility: James McClintock,

Birmingham, Alabama, USA
Storfer A, Sih A (1998) Gene flow and ineffective antipredator behavior in a stream-breeding salamander. Evolution 52: 558-565

> Sullivan AM, Madison DM, Rohr JR (2004) Variation in the antipredator responses of three sympatric plethodontid salamanders to predator-diet cues. Herpetologica 60: 401-408

Tokeshi M, Estrella C, Paredes C (1989) Feeding ecology of a size-structured predator population, the South American sun-star Heliaster helianthus. Mar Biol 100:495-505

> Trussell GC (2000) Phenotypic clines, plasticity, and morphological trade-offs in an intertidal snail. Evolution 54: 151-166

Trussell GC, Ewanchuk PJ, Matassa CM (2006) The fear of being eaten reduces energy transfer in a simple food chain. Ecology 87:2979-2984

Vermeij GJ (1982) Unsuccessful predation and evolution. Am Nat 120:701-720

Werner EE, Gilliam JF, Hall DJ, Mittelbach GG (1983) An experimental test of the effects of predation risk on habitat use in fish. Ecology 64:1540-1548

Wieters EA, Gaines SD, Navarrete SA, Blanchette C, Menge BA (2008) Scales of dispersal and the biogeography of marine predator-prey interactions. Am Nat 171: 405-417

Yamada SB, Navarrete SA, Needham C (1998) Predation induced changes in behavior and growth rate in three populations of the intertidal snail, Littorina sitkana. J Exp Mar Biol Ecol 220:213-226

Submitted: July 7, 2010; Accepted: October 15, 2010

Proofs received from author(s): December 30, 2010 